\title{
МОНІТОРИНГ ПРИРОДНОГО ВІДНОВЛЕННЯ БЕРЕКИ ЛІКАРСЬКОЇ В ДУБОВО-ГРАБОВИХ ДІБРОВАХ ПІВДЕННО-ПОДІЛЬСЬКОГО ЛІСОСТЕПУ УКРАЇНИ
}

На території Національного природного парку "Кармелюкове Поділля" у свіжих дубово-грабових дібровах природного $і$ штучного походження збережено раритетний вид береки лікарської (Sorbus torminalis (L.) Crantz). Цей надзвичайно цінний компонент наших лісів бере участь у формуванні другого ярусу лісостану, є досить декоративною, лікарською, деревною породою, що має їстівні плоди. Природоохоронний статус виду неоціненний, наукове значення - зникаючий вид, але, на жаль, сьогодні природному насіннєвому відновленню популяції не приділяють належної уваги. За останні п'ять років виявлено одиничне природне насіннєве поновлення виду у 49 кварталах регіону дослідження. Під час переліку деревостанів виявлено значну кількість особин Sorbus torminalis віком 18-25 років, що свідчить про здатність виду до природного поновлення за сприятливих умов. 3 метою глибшого вивчення та забезпечення природного поновлення виду розроблено "Програму щодо збереження та відтворення береки лікарської (Sorbus torminalis (L.) Crantz) на території Національного природного парку "Кармелюкове Поділля" на 2018-2021 pр." Проаналізовано динаміку кількісного та якісного стану виду в умовах свіжої дубово-грабової діброви. Таксаційна характеристика насаджень з поновленням Sorbus torminalis переважно складається з 6-8 одиниць дуба, 2-3 одиниць граба, 1-2 одиниць ясена. Менше одиниці становлять інші супутні породи, зокрема Sorbus torminalis. Середня висота Sorbus torminalis у насадженнях - 12,5-20,7 м, середній діаметр відповідно - 9,8-21,1 см. Клас бонітету - I, I вання саджанців Sorbus torminalis і використання їх у створенні ландшафтних композицій, що також сприятиме поширенню виду. Для того, щоб отримати генетично однорідний матеріал використано метод мікроклонального розмноження Sorbus torminalis у культурі in vitro. Звернено увагу на втілення лісогосподарських заходів відносно збереження і відновлення береки лікарської в регіоні.

Ключові слова: Sorbus torminalis; сіянці; підріст; дубово-грабова діброва; НПП "Кармелюкове Поділля"; Південно-Подільський Лісостеп.

Вступ. Основним методом відновлення лісів, який сприяє збереженню формового різноманіття порід, вважають природне відновлення. Значну увагу цій проблемі приділяють у період сучасного поступового потепління, зростання сухості клімату та динамічного розширення площ природно-заповідного фонду, основу якого переважно формують деревостани за участю дуба звичайного (Quercus robur L.) і граба звичайного (Carpinus betulus L.)

Значна частина території НПП "Кармелюкове Поділля" (90 \%) представлена дібровами природного походження 3 переважанням у складі деревостанів дуба звичайного (Quercus robur L.), дуба скельного (Quercus petraea Liebl.), граба звичайного (Carpinus betulus L.), ясена звичайного (Fraxinus excelsior L.) та інших лісоформувальних порід. У другому ярусі трапляється субсередземноморський вид, занесений до Червоної книги України, берека лікарська (Sorbus torminalis (L.) Crantz). Такі насадження практично відсутні на територіях природно-заповідних об'єктів України (Zakharov, 1967; Litopys pryrody, 2018).

За даними В. В. Буджака (Budzhak, 1996), Sorbus torminalis належить до видів, чисельність популяцій яких у межах території Північної Буковини та Північної Бессарабії за останні 100 років різко скоротилася. Попри велику господарську цінність високоякісної деревини, лікарські властивості плодів та прекрасні декоративні властивості, Sorbus torminalis стала забутою та маловідомою рослиною, а С. М. Стойко вважає, що із зазначених вище територій вона, ймовірно, вже зникла (Svyrydenko, Babich \& Kyrychok, 2004). Учені-лісівники M. I. Гордієнко і А. О. Бондар вважають, що кращими супутніми та підгінними породами в культурах Quercus robur можуть бути Sorbus torminalis, Prunus avium L., Pyrus piaster L. та ін. (Bodnar \& Hordiienko, 2006).

Особливої уваги в дубово-грабових насадженнях НПП "Кармелюкове Поділля" заслуговує забезпечення природного насіннєвого відновлення популяції Sorbus torminalis, якому раніше не приділяли належну увагу. Проведений аналіз показав, що популяція виду потребує докладнішого і глибшого вивчення. Для відтворення і розширення ареалу рекомендовано введення цієї породи в лісові культури. Також необхідно виконувати систематичні роботи щодо виявлення місць їі зростання, постійно спостерігати за станом популяції і створювати на територіях системи заповідних та інших об'єк-

Інформація про авторів:

Шпак Ніна Петрівна, наук. співробітник. Email: spaknina0@gmail.com

Цитування за ДСтУ: Шпак Н. П. Моніторинг природного відновлення береки лікарської в дубово-грабових дібровах ПівденноПодільського Лісостепу України. Науковий вісник НЛтУ України. 2019, т. 29, № 5. С. 27-30.

Citation APA: Schpak, N. P. (2019). Monitoring of Natural Regeneration of Sorbus Torminalis (L.) Crantz Species in the Conditions of South Podillya Forest-Steppe of Ukraine. Scientific Bulletin of UNFU, 29(5), 27-30. https://doi.org/10.15421/40290505 
тів, що особливо охороняються. Відновлені насіннєвим способом дубові деревостани з участю Sorbus torminalis відзначаються кращим ростом, характеризуються високою стійкістю до несприятливих умов навколишнього середовища, довговічністю, значним меліоративним впливом (Hordiienko, Bondar \& Krynytskyi, 2006; Makhmet, 1965; Shpak, Shlapak \& Leontiak, 2017).

3 метою глибшого вивчення та забезпечення природного відновлення зникаючого виду розроблено "Програму щодо збереження та відтворення береки лікарської (Sorbus torminalis (L.) Crantz) на території Національного природного парку "Кармелюкове Поділля" на 2018-2021 pp." На основі досліджень та моніторингу за станом Sorbus torminalis, системи заходів, спрямованих на іiї збереження та відтворення у природних комплексах, передбачено виконання таких основних завдань: збереження та відтворення корінних лісових насаджень; вивчення оселищ Парку як Смарагдового об'єкта, подальшу інвентаризацію та картування іiі місцезнаходжень як зникаючого виду (Stoiko, 2009; Shpak \& Dudnyk, 2015). Культивування раритетних видів рослин 3 метою збереження їхнього генофонду $є$ одним 3 основних завдань сучасності, оскільки зміни природних територій, їхня деградація, спричинені діяльністю людини та змінами клімату, прискорюють зникнення видів та популяцій (Shpak, 2018a, 2018b, 2018c).

Об'єкти і методика дослідження. Дослідження проводили у свіжих дубово-грабових, дубово-грабовоясеневих дібровах з участю Sorbus torminalis, які розташовані на території Бершадського, Крижопільського, Тростянецького, Чечельницького р-нів Вінницької обл.

Sorbus torminalis - об'єкт природної популяції Південного Поділля, аборигенний вид, компонент другого ярусу світлих широколистяних лісів, мезофіт, кальцефіл. В Україні проходить крайня північно-східна межа поширення цього виду (Bodnar, 2002; Budzhak, 1996).

Основними методами дослідження були докладні маршрутні та напівстаціонарні методи, зокрема: закладання постійних пробних площ, моніторингових ділянок, картування місць знаходження виду; метод окомірного еколого-ценотичного профілювання; лісівничотаксаційні, порівняльної екології; геоботанічні, фітоіндикаційні, математико-статистичні (Alekseev, 1989; Anuchin, 1977; Pogrebniak, 1968; Piatnitckii, 1976). Для визначення лісівничо-таксаційних показників деревостану, підліску, підросту, трав'яного покриву і різновидів грунту використовували додатки із "Практикуму 3 лісівництва" за редакцією (Piatnitckii, 1976). Оцінювали успішність природного відновлення за шкалою УкрНДІЛГА, згідно з якою підріст поділяли за такими показниками: стан життєздатності - благонадійний, сумнівний, неблагонадійний і загиблий; висота - дрібний (0,1-0,5 м), середній (0,51-1,5 м) і великий (1,51 м і вище); вік - до 1 року, 2-3-річний, 4-8-річний і 9-15-річний. Для проведення досліджень закладено 37 тимчасових та 11 постійних пробних площ. Тип лісорослинних умов - свіжа дубово-грабова діброва (Д 2 Г), з різною формою рельєфу.

Результати дослідження. Ліси Вінниччини сьогодні займають близько 14,4 \% іï загальної площі, що робить область малолісною і лісодефіцитною. Для формування високопродуктивних насаджень вводяться породи, які мають цінну деревину, є медоносами, а плоди їх поїдають дикі тварини і птахи. До таких порід нале- жить і Sorbus torminalis. Питанню з природного відновлення береки лікарської приділив увагу Б. М. Махмет, який відзначає інтенсивне поновлення Sorbus torminalis у цьому регіоні (10-11,2 тис. самосіву і підросту різного віку на гектар) (Vorobev, 1967). На жаль, такої кількості насіннєвого відновлення виду в насадженнях і на зрубах ми не виявили. Лісівники А. О. Бондар і М. I. Гордієнко звертають увагу на відновлення Sorbus tormina$l i s$, яка залишена на зрубах та в мішаних насадженнях.

Під час дослідження визначали співвідношення деревних порід у дубово-грабових деревостанах з участю Sorbus torminalis. Обстежили 108 кварталів, у яких переважає Quercus robur. Береку, черешню, грушу, берест віднесли до інших порід. Насадження з участю Sorbus torminalis на території НПП трапляється у 82-х кварталах і становить 1244,2 га. У межах природоохоронних науково-дослідних відділень парку: Бритавське - 664 га (48 \%), Лузьке - 223,6 га (16 \%), Дохнянське - 141,8 га (10\%), Червоногребельське - 356,5 га (26\%). Кількість особин Sorbus torminalis серед інших деревних порід у кварталах різна і становить від 0,6 до $19 \%$, середня кількість особин у деревостанах - близько біля $2 \%$ (рис. 1).

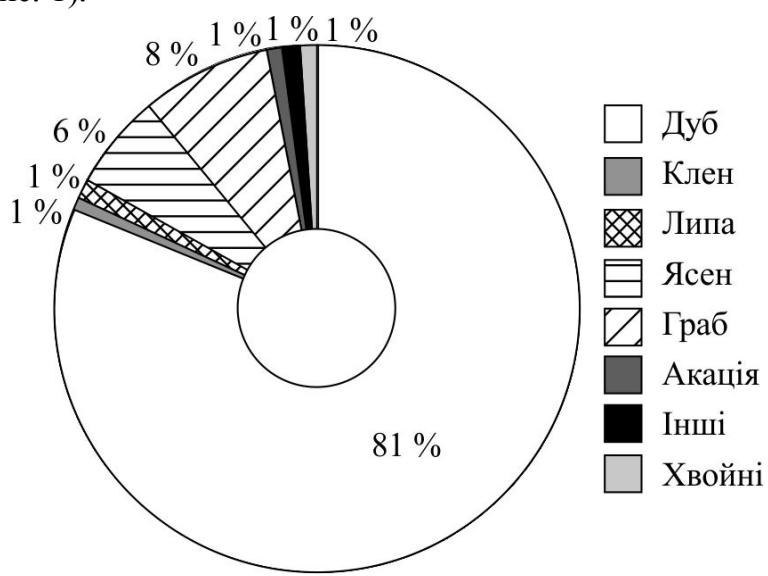

Рис. 1. Співвідношення деревних порід у свіжих дібровах

Нерівномірний розподіл виду залежить від віку та складу насаджень, рельєфу, генетичного типу і механічного складу грунтів та інших природних чинників. Перевага особин 3 діаметром 8-12 см свідчить про те, що в сприятливих умовах попередніх років відбувалося природне поновлення виду за рахунок насінників, які залишалися після вживання господарських заходів. Відсутність дерев I і II категорій свідчить про високу повноту деревостанів (таблиця).

Швидкість росту береки лікарської у висоту перевищує ріст стовбура у товщину, у віці 20-25 років може мати діаметр 10-12 см. Щільна крона дерева нагинає стовбур. Підріст береки лікарської трапляється віком від 1-го до 9 років 3 діаметром пагонів 0,5-6 см. Природне поновлення виду досліджували різними методами. Під час окомірного методу встановлювали загальну картину поновлення - приблизна його густота та розміщення молодих рослин (рівномірне чи групове). Також визначали стан підросту: здоровий, пошкоджений, хворий, сумнівний.

Природне насіннєве поновлення Sorbus torminalis виявили у 49 кварталах Парку. Методом стрічкових проб визначили кількість підросту, який змінюється від 12 до 54 особин на 1 га (рис. 2). За останні 10 років природне поновлення Sorbus torminalis дуже слабке. 
Таблиця. Таксаційні показники виду в регіоні дослідження

\begin{tabular}{|c|c|c|c|c|c|c|c|c|c|c|c|}
\hline \multirow{3}{*}{ Вікова група } & \multirow{3}{*}{$\begin{array}{l}\text { Кількість особин береки в } \\
\text { перерахунку на } 1 \text { га (шт.) }\end{array}$} & \multicolumn{10}{|c|}{ Середня кількість особин за показниками (\%) } \\
\hline & & \multicolumn{6}{|c|}{ діаметр стовбура } & \multicolumn{4}{|c|}{ категорія } \\
\hline & & 8 & 12 & 16 & 20 & 24 & 28 & III & IV & $\mathrm{V}$ & VI \\
\hline Молодняки & 65 & 58 & 29 & 9 & 4 & - & - & - & 86 & 12 & 2 \\
\hline Середньовікові & 109 & 42 & 35,5 & 8 & 6 & 4,6 & 0,9 & 3 & 89 & 1 & 7 \\
\hline Пристигаючі & 158 & 8 & 33 & 38 & 12 & 3 & 6 & - & 58 & 28 & 14 \\
\hline Стиглі та перестійні & 48 & 8 & 11 & 21 & 31 & 21 & 8 & 21 & 73 & 6 & - \\
\hline Всього & 95 & 29 & 27 & 19 & 13 & 7 & 4 & 6 & 77 & 12 & 6 \\
\hline
\end{tabular}

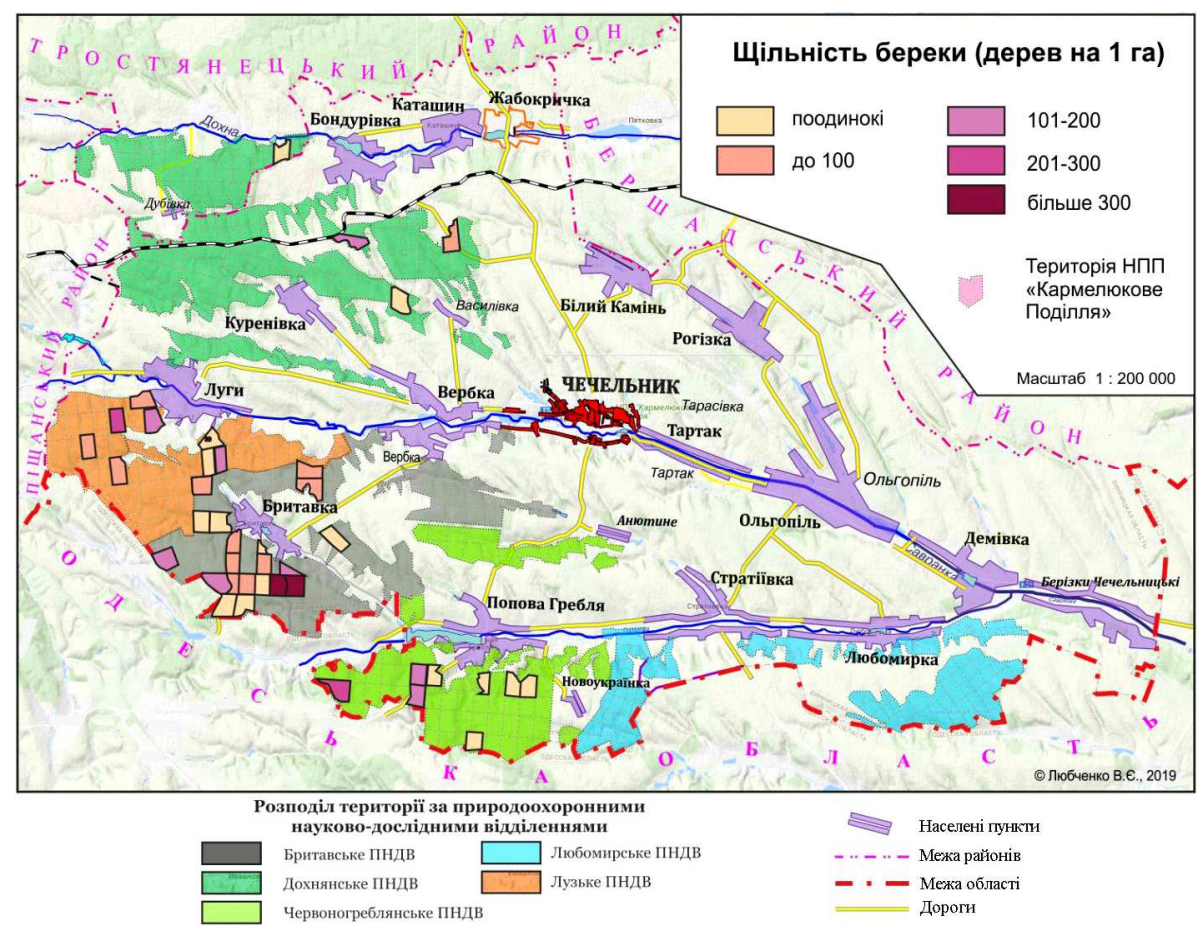

Рис. 2. Щільність популяції береки лікарської в лісових масивах

Таксаційна характеристика насаджень 3 поновленням Sorbus torminalis переважно складається з 6-8 одиниць дуба, 2-3 одиниць граба, 1-2 одиниць ясена. Менше одиниці становлять інші супутні породи, зокрема Sorbus torminalis. Середня висота Sorbus torminalis у насадженнях - 12,5-20,7 м, середній діаметр відповідно 9,8-21,1 см. Клас бонітету - I, I ${ }^{\mathrm{a}}$, відносна повнота - 0,70,8 , запас стовбурної деревини насаджень - 140$310 \mathrm{~m}^{3} /$ га. Намет основного деревостану характеризується високою зімкненістю та складається переважно із крон головних лісоутворювальних порід. Найбільшу кількість підросту береки лікарської нарахували під вікнами намету, в місцях розрідженого стояння дерев, по краю стіни лісу. У Лузькому ПНДВ (кв. 10/6, вік 45 р.) кількість сіянців - 28 шт. на 1 га. Найбільша кількість підросту (54 екземпляри) трапляється у середньовікових насадженнях (Бритавське ПНДВ, кв. 82/4, вік 60 років). Найменшу кількість підросту (16-20 особин, кв. 84/1) виявили у вікових насадженнях Бритавського ПНДВ. Зменшення кількості підросту зі збільшенням віку насадження пояснюємо посиленням конкуренції за поживні речовини, світло та вологу, зменшення або відсутність плодоношення. Поодинокі сіянці Sorbus torminalis трапляються майже на всіх пробах, але їхній стан переважно незадовільний. Основними причинами випадання сіянців та підросту є висока повнота деревостану, значне поширення в підрості граба, ясена, які є швидкорослими породами і пригнічують підріст дуба звичайного та береки лікарської.

Незначна кількість сходів залежить від біологічних і морфологічних особливостей плодів і насіння. За не- достатньої вологості восени шкірка плоду всихає і стає непроникною для зародкового корінця, насіння переходить у стан глибокого спокою. Чимало ростків не здатні пробитися через товсту підстилку і дійти до поживного мінерального шару грунту. Сходи ніби зависають у них і гинуть.

3 огляду на те, що Sorbus torminalis не вирубують, вегетативного поновлення поросллю від пенька ми не виявили. У разі пошкодження сіянців тваринами відбувається відновлення пагонів, яких з'являється по 2-3. За коренепаростковою здатністю відновлення С. С. П'ятницький відносять Sorbus torminalis до 3 групи дерев, які дають тільки регенеративні паростки, що з'являються під час рубання або пошкодження материнського дерева. У разі пошкодження поверхневих коренів Sorbus torminalis коренепаросткове поновлення зустрічали дуже рідко, паростки нежиттєздатні, тому згодом, не піднявшись, гинуть.

Висновки. Як відомо 3 практики, деревні породи 3 природним насіннєвим походженням $є$ найстійкішими та найбільш довговічними. Тому варто впроваджувати лісогосподарські заходи, спрямовані на природне насіннєве відновлення дубових лісостанів з участю Sorbus torminalis.

За сталих екологічних умов та дотримання необхідного заповідного режиму Sorbus torminalis може не тільки зберегти свій нинішній стан популяції, але і розширитися надалі.

У цих умовах, за достатнього режиму освітленості та видалення самосіву граба звичайного, можливе відновлення береки лікарської насіннєвим шляхом за умо- 
ви вживання своєчасних та ретельних відповідних лісогосподарських заходів.

\section{Перелік використаних джерел}

Alekseev, V. A. (1989). Diagnostika zhiznennogo sostoianiia derevev i drevostoev. Lesovedenie, 4, 51-57. [In Russian].

Anuchin, N. P. (1977). Lesnaia taksatciia. Moscow, 512 p. [In Russian].

Bodnar, A. O. (2002). Bereka v lisovykh nasadzhenniakh. Vinnytsia, 64 p. [In Ukrainian].

Bodnar, A. O., \& Hordiienko, M. I. (2006). Formuvannia lisovykh nasadzhen u dibrovakh Podillia. Kyiv, 336 p. [In Ukrainian].

Budzhak, V. V. (1996). Bereka (Sorbus torminalis (L.) Crantz) u pivnichnii Bukovyni ta pivnichnii Bessarabii (khronolohiia, bioekolohiia, okhorona). Candidate dissertation for biology sciences. Chernivtsi, 293 p. [In Ukrainian].

Hordiienko, M. I., Bondar, A. O., \& Krynytskyi, H. T. (2006). Lisovi nasadzhennia Vinnychchyny. Kyiv, 248 p. [In Ukrainian].

Litopys pryrody. (2018). Litopys pryrody NPP "Karmeliukove Podillia". Chechelnyk. (Vol. 5), 224 p. [In Ukrainian].

Makhmet, B. M. (1965). Kultura bereky v Ukrainskii RSR. Kyiv, 92 p. [In Ukrainian].

Piatnitckii, S. S. (1976). Metodika issledovaniia estestvennogo semennogo vozobnovleniia $v$ lesakh Levoberezhnoi Lesostepi Ukrainy. Kharkiv: Lesn. prom-st, 117 p. [In Russian].

Pogrebniak, P. S. (1968). Obshhee lesovodstvo. (2nd ed.). Moscow: Publishing house "Kolos", 439 p. [In Russian].

Shpak, N. P. (2018a). Inventaryzatsiia vydu Sorbus torminalis (L.) Crantz yak neobkhidnyi zakhid dlia yoho okhorony ta zberezhennia. Key Issues of Education and Sciences: Development Prospects for Ukraine and Poland: International Multidisciplinary Conference, (pp. 76-78), July 20-21. Stalowa Wola Republic of Poland. [In Ukrainian].

Shpak, N. P. (2018b). Fruiting and natural restoration of Sorbus Torminalis (1.) Crantz under the oak stands canopy in the SouthPodilsky forest-steppe of Ukraine. Scientific Bulletin of UNFU, 28(10), 53-56. https://doi.org/10.15421/40281011

Shpak, N. P. (2018c). Osoblyvosti sezonnoho rozvytku i dekoratyvnist vydiv rodu Sorbus L. v umovakh Pivdenno-Podilskoho Lisostepu Ukrainy. Introduktsiia roslyn na Volyno-Podilli: nauka, osvita, mystetstvo formuvannia landshaftu, vyrobnytstvo: Materialy Mizhnarodnoi naukovo-praktychnoi konferentsii, (pp. 130-135), May 17-18. Ternopil: Ternopilskyi oblasnyi komunalnyi instytut pisliadyplomnoi pedahohichnoi osvity. [In Ukrainian].

Shpak, N. P., \& Dudnyk, H. L. (2015). Suchasnyi stan populiatsii Sorbus torminalis v umovakh NPP "Karmeliukove Podillia", (pp. 8084). Vinnytsia: FOP Korzun D. Yu. [In Ukrainian].

Shpak, N. P., Shlapak, V. P., \& Leontiak, H. P. (2017). Some peculiarities of cultivation of common oak stands involving bereka medicinal in Southern Podillya. Scientific Bulletin of UNFU, 27(3), 71-74. https://doi.org/10.15421/40270315

Stoiko, S. M. (2009). Dubovi lisy Ukrainskykh Karpat: ekolohichni osoblyvosti, vidtvorennia, okhorona, (pp. 151-155). Lviv. [In Ukrainian].

Svyrydenko, V. Ye., Babich, O. H., \& Kyrychok, L. S. (2004). Lisivnytstvo. Kyiv: Aristei, 544 p. [In Ukrainian].

Vorobev, D. V. (1967). Metodika lesotipologicheskikh issledovanii. Kyiv: Publishing house "Urozhai", 388 p. [In Russian].

Zakharov, V. K. (1967). Lesnaia taksatsyia. Moscow: Lesnaia promst, 408 p. [In Russian].

\section{MONITORING OF NATURAL REGENERATION OF SORBUS TORMINALIS (L.) CRANTZ SPECIES IN THE CONDITIONS OF SOUTH PODILLYA FOREST-STEPPE OF UKRAINE}

Sorbus torminalis (L.) Crantz, an extremely valuable component of our forests, has been preserved in fresh oak and hornbeam forests of natural and artificial origin with a various form of relief of Karmelyukove Podillya National Nature Park. It participates in the formation of the second tier of the tree stand, and is decorative and medicinal wood species having edible fruits. The nature conservation status of the species is invaluable, the scientific significance is an endangered species, but the natural seed restoration of the population was not given proper attention. Over the past 5 years, a single natural seed update has been discovered in 49 quarters of the research area. A large number of individuals aged from 18 to 25 years are included in the list of trees, which indicates the ability of Sorbus torminalis to undergo natural regeneration under favourable conditions. In order to further study and ensure the natural regeneration of the species, the Program of Conservation and Restoration (Sorbus torminalis (L.) Crantz) was developed on the territory of Karmelyukove Podillya National Nature Park for the period of 2018-2021. The dynamics of quantitative and qualitative state of the species under conditions of oak-hornbeam forests is analyzed. Estimated features of planting with proceeding in Sorbus torminalis is as follows: it mainly consists of 6-8 oak trees, 2-3 hornbeam trees, and 1-2 ash trees. Other contiguous species show less number, including Sorbus torminalis. An average height of Sorbus torminalis in planting ranges from 12.5 to $20.7 \mathrm{~m}$, average diameter accordingly ranges from 9.8 to $21.1 \mathrm{~cm}$. Class bonitet is I, I $\mathrm{I}^{\mathrm{a}}$, relative plenitude is $0.7-0.8$, stem wood stock of planting is $140-310 \mathrm{~m}^{3}$. Special attention is paid to growing of seedlings of Sorbus torminalis and their use in creation of landscape compositions that will promote the species distribution as well. In an order to get genetically homogeneous material, we used the method of microclonal reproduction of Sorbus torminalis in vitro. The attention was also paid to the implementation of a number of forest management measures for the conservation and restoration of Sorbus torminalis in the region.

Keywords: Sorbus torminalis; growth; seedlings; fresh oak and hornbeam forests; NNP Karmelyukove Podillya NNP; SouthPodillya Forest-steppe. 